\title{
The Theology of the Holy Eucharist and the Doctrine of Transubstantiation
}

\author{
Francis Appiah-Kubi ${ }^{1}$ \\ ${ }^{1}$ Department of Religious Studies, Kwame Nkrumah University of Science and Technology, Kumasi-Ghana.
}

\begin{abstract}
Holy Communion is one of the seven sacraments in the Catholic Church. With Baptism and Confirmation, they constitute the sacraments of Initiation. Similarly, with the Word of God, they constitute the two indispensable pillars upon which the Church is built. It is the "fount and apex of the whole Christian life" (LG 11). It is named Holy Eucharist because it is an action of thanksgiving to God. It recalls God's work of creation, redemption, and sanctification. The Eucharistic elements, bread and wine become, by the prayer of consecration and the invocation of the Holy Spirit, Christ's Body and Blood through an act appropriately known as transubstantiation. The term emphasizes the conversion of the total substance of bread and wine into the entire substance of the Body and Blood of Christ. When the bread and wine are consecrated at Mass, they are no longer bread and wine; they have become instead the Most Precious Body and Blood of Christ by the power of the Holy Spirit in accordance with the words of Christ. The empirical appearances and attributes remain the same, but the underlying reality changes. Therefore, the doctrine of transubstantiation teaches without ambiguity that in the Holy Communion, the Body and Blood, together with the soul and divinity, of the Lord Jesus Christ is truly, really, and substantially contained. How is this understood and what is its implication theologically? In an attempt to elucidate this problem, this work seeks first to highlight the theology of the Holy Eucharist within the context of the ecclesiology of Communion, and second, through some theological themes: sacred memorial and sacrificial banquet; eschatological meal. The third and final part treats the theme of real presence under the rubrics of Transubstantiation.
\end{abstract}

Keywords: Transubstantiation, Eschatological Meal, Memorial, Real Presence, Communion, Eucharistic conversion.

\section{INTRODUCTION}

From the perspective of the Catholic Church, O. Ludwig defines the Eucharist as "that sacrament, in which, Christ, under the forms of bread and wine, is truly present, with His Body and Blood, to offer Himself in an unbloody manner to the Heavenly Father, and to give Himself to the faithful as nourishment for their souls." It is learnt from the Second Vatican Council Dogmatic Constitution on the Church, Lumen Gentium, that the Church's ultimate vocation is to maintain and promote communion with the triune God and communion among the faithful. For this purpose, she possesses the Word of God, Dei Verbum, and the sacraments, especially the sacrament of the Eucharist, by which she constantly lives and grows,${ }^{2}$ and expresses her very nature. The Council emphasizes that the Eucharist is the height of all the sacraments in perfecting communion with God the Father. ${ }^{3}$ It identifies believers with His Son [Christ] through the workings of the Holy Spirit. "Unlike any other sacrament", in the Eucharist, "the mystery of communion is perfected. This perfection brings Christians into the heights and goals of every human desire, for in the Eucharist they reciprocally attain God

\footnotetext{
Ott Ludwig, Fundamental of Catholic Dogma, Illinois, (Tan Books and Publishers, (4 ${ }^{\text {th }}$ Edition), 1960), 370.

Second Vatican Council, Dogmatic Constitution on the Church, Lumen Gentium, 26.

Lumen Gentium 11.
} 
and God joins himself to humanity in the most perfect union. ${ }^{4}$ It is therefore not by chance that the expression $\mathrm{Holy}$ Communion has become one of the designated names for this sublime sacrament.

The Church, affirms Pope John Paul II in his encyclical letter Ecclesia de Eucharistia, has "received the Eucharist from Christ her Lord not only as one gift - however precious - among so many others but as the gift par excellence, for it is the gift of himself, of his person in his sacred humanity, as well as the gift of his saving work." The Eucharist becomes a creative force and source of communion among the members of the Church, precisely because it unites each communicant to the rest with Christ himself. Effectively, the Congregation for the Doctrine of Faith affirms that "sharing in the body of the Lord in the breaking of the Eucharistic bread, we are taken up into communion with Him and with one another, for the bread is one, we, though many, are one body, all of us who partake of the one bread, (1Cor 10:17)." ${ }^{6}$ This is the more reason why the Catholic Church deems herself as Eucharistic Church because the Church effects the Eucharist and the Eucharist builds the Church.

The Second Vatican Council Constitution on Sacred Liturgy, Sacrosanctum Concilium, reasserts:

During the Last Supper, on the night he was betrayed, our Saviour instituted the Eucharistic sacrifice of his Body and Blood. This he did to perpetuate the sacrifice of the Cross throughout the ages until he should come again, and so to entrust to his beloved Spouse, the Church, a memorial of his death and resurrection: a sacrament of love, a sign of unity, a bond of charity, a Paschal banquet, in which Christ is consumed, the soul is filled with grace, and a pledge of future glory is given to us.?

Indeed, Jesus Christ designated those who can celebrate the Eucharist, the Apostles and their successors in the priesthood $; 8$ and he conferred the power to celebrate it and determined the basic elements of the rite: the same ones that he employed. Par consequent, the celebration of the Eucharist requires bread and wine, ${ }^{9}$ the prayer of thanksgiving and blessing, the consecration of the gifts into the Body and Blood of the Lord, and the distribution of and communion with this most sacred Sacrament. ${ }^{10}$ From the general instructions in the Roman Missal and according to Catholic theology, it is stipulated convincingly and without ambiguity that the essential and necessary elements for the sacramental sign of the Eucharist are bread made from wheat flour ${ }^{11}$ and wine made from grapes, ${ }^{12}$ along with the words of consecration that the priest pronounces in persona Christi in the Eucharistic Prayer.

The Catechism of the Catholic Church reiterates the affirmation according to which and due to the effectiveness of Jesus's words and the power of the Holy Spirit, the bread and the wine are converted into efficacious signs, with ontological reality and not merely as a sign, of the presence of the Body given up and the Blood poured out by Christ, but his Person and his redemptive sacrifice.$^{13}$ It is required of Catholics to profess that "the Eucharist is the flesh of Our Savior Jesus Christ which suffered for our sins and which the Father in His loving kindness raised again." 14 Faithful to Jesus' commandment, the Church, guided by the Spirit of truth (Jn 16:13), the Holy Spirit, when she celebrates the Eucharist does no more than following the Eucharistic rite as performed by Jesus at the Last Supper.

\section{Holy Communion Put to Test}

Paradoxically, Christians over the centuries have divided themselves into different sects partly on their views and understandings concerning the Eucharist. The wounds of division are so deep and scandalous when one considers the fact that the very sacrament of unity and communion among Christians is at the same time at the heart of controversy and division among them. The Eucharist and the doctrine of transubstantiation have raged in the Church more seriously since the Protestant Reformation to date. In 1950, Pope Pius XII issued the encyclical Humani Generis which addressed "some false opinions threatening to undermine the foundations of Catholic doctrine." 15 Among the errors acknowledged, he mentioned those relating to the Eucharist with brevity and clarity. He was responding to some critics who argued that the doctrine of transubstantiation, based on an old philosophical notion of substance, should be so modified that the real presence of Christ in the Holy Eucharist be seen as a kind of symbolism. In that sense, the consecrated species would be simply and merely efficacious signs of the spiritual presence of Christ and His intimate union with the faithful members 
of His Mystical Body. ${ }^{16}$ Succinctly it is an attempt towards understanding the real presence of the Body of Christ in the Eucharist not insisting anymore on the old notion of substance and not speaking of transubstantiation in the ontological sense of the word. ${ }^{17}$ The next decade and a half saw certain theologians, both Catholics, and Protestants, trying to revise the traditional formulae in favour of expressions such as transignification or transfinalization. ${ }^{18}$

These days, even more, tragic is how the Holy Communion or the Eucharist has been domesticated with dominant social ramifications. The radical demands of the Eucharist have been largely neutralized in some Christian circles to the point that even the doctrine or the certainty that "the Eucharist is the source and summit of Christian life" 19 can only be amply justified theologically. Many people are more interested in the Gospel or Word of God and speaking in tongues than in the reception of the Eucharist (Holy Communion) ${ }^{20}$ The integral vision of the divine plan for the salvation of humanity is much neglected and people are going away from the Church, the body of Christ, and for personal experiences. Pope John Paul II expressed his profound grief about how the mystery of the Holy Eucharist has been downplayed. He decried:

In some places, the practice of Eucharistic adoration has been almost abandoned. In various parts of the Church, abuses have occurred, leading to confusion concerning sound faith and Catholic doctrine concerning this wonderful sacrament. At times one encounters an extremely reductive understanding of the Eucharistic mystery. Stripped of its sacrificial meaning, it is celebrated as if it were a fraternal banquet. ${ }^{21}$

Certainly, some pertinent questions run through the minds of many today: How is it possible that the Sacrifice of Christ can be repeated time and again although Christ entered the sanctuary once and for all (Heb 9:12), and that he does not have to offer himself again and again (Heb 9:25)? How is it possible that the Eucharist can be a sacrifice; the true Body and Blood of Christ? How does the Sacrifice of the Cross relate to the sacrifice of the Eucharist? How can believers come to terms with this mystery of the Holy Communion as a gift par excellence, a gift of Christ himself? And what is the term transubstantiation trying to elucidate and defend?

\section{TOWARDS THE UNDERSTANDING THE HOLY EUCHARIST}

It must be stated that throughout history, several other names or appellations have been employed to designate the Eucharist or Holy Communion; It is at times called the Lord's Supper (Coena Domini), the Table of the Lord (Mensa Domini), the Holy of Holies (Sanctissimum), the Lord's Body (Corpus Domini), the breaking of the bread (Fractio Panis), the Sacrifice of the altar, the Most Blessed Sacrament, agape (Love-Feast), Synaxis (Assembly), ${ }^{22}$ etc. Etymologically, the word Eucharist comes from the Greek eucharistia, ${ }^{23}$ "thanksgiving". Its verbal form eucharistein meaning "to give thanks" ${ }^{24}$ is "used in liturgical texts on Jesus' Last Supper and the texts influenced by the early Christian Eucharist." 25 It also refers to the people of God together, united in communion or fellowship, as the body of Christ - who is the one and only minister and high priest. Unity is experienced in the communion of sharing in the paschal meal - the body and blood of Jesus in the appearances of bread and wine offered in sacrifice by the priest and with the church, the body of Christ. From his liturgical studies, T. Mathew reaffirmed that the terms Eucharistia and eucharistein were "used in early Christian language as translations of the Hebrew verb barak and the noun berakah. When translated into Greek as eulogein, it means to bless, and eulogia, means blessing. ${ }^{26}$ One can therefore agree with Pope Paul VI when he writes that the Eucharist, a thanksgiving offering is equally "the sacrifice of the New Covenant in which Christ, through the ministry of the priest, offers himself to God in an unbloody manner under the appearances of bread and wine." ${ }^{27}$ The Eucharist is par consequent, "the sacrament in which Christ is really and truly present under the appearances of bread and wine." ${ }^{28}$

According to P. Stravinskas, the Eucharist "is the Sacrament of the Body and Blood of Jesus Christ, in which He [Christ] is present under the forms of bread and wine offering Himself in the Sacrifice of the Mass and giving himself as spiritual food to the faithful." ${ }^{29}$ In the same perspective H. Scott sees the Eucharist as "an efficacious sign of the

\footnotetext{
16 Pope Pius XII, Humani Generis, 26.

17 Cf. Reginald Garrigou-Lagrange, “The Structure of Humani Generis”, (La Sintesi tomistica), (Brescia, Queriniana, 1953), 541-544.

18 Cf. Edward J. Gratsch et al. (Eds.) Principles of Catholic Theology, (New York, Society of St. Paul, 1981 ), 186.

19 Lumen Gentium, 11.

20 Cf. Paul VI, Mysterium Fidei, \# 10 \& \# 54...

John Paul II, Ecclesia de Eucharistia, 15-16.

Hahn Scott, Catholic Bible Dictionary, (New York, Doubleday, 2009), 255.

23 Richard P. McBrien, Catholicism (San Francisco/New York, Harper/Collins Publishers, 1994), 1239.

Paul F. Bradshaw, (Ed.), Eucharist, The New SCM Dictionary of Liturgy and Worship, (London: SCM Press, 2002), 172-173.

25 Thomas Mathew, "Significance of Sacraments of Initiation," (PhD dissertation, Katholieke Universiteit Leuven, 2008), 157

Mathew, "Significance of Sacraments of Initiation", 157.

Paul VI Mysterium Fidei, 34.

Scott, Catholic Bible Dictionary, 255; Catechism of the Catholic Church (CCC), 1324; Code of Canon Law, Canon 904.

Peter M. J. Stravinskas, (Ed.), Our Sunday Visitor's Catholic Encyclopedia (Huntington: Our Sunday Visitor Inc., 1991), 368. The definitions emphasis the sacrificial and meal dimension of the Eucharist.
} 
sacrifice offered by Christ on the Cross." ${ }^{30} \mathrm{He}$ insists that Christ offers himself to the Father in the Mass just as he did on the Cross, but the offering is made through the consecratory action of the priest [...]. More importantly, the Eucharist is unique because of the real presence of Christ under the appearance of bread and wine."31

\section{Eucharist: Memorial and Sacrificial Banquet}

One way of appreciating the Holy Eucharist is under the rubric of God's attempt to restore the sacred banquet, the convivial sharing of grace with creation. The notion of a memorial banquet that had a fixed place in the paschal feast has been expressed explicitly by Christ to contrast the Old and New Pasch and to indicate His [Christ] desire to have this Eucharistic celebration continued. E.J. Kilmaritin recognizes that the Eucharist as the memorial banquet of the new dispensation involves the representation, the re-actualization of the redemptive work of Jesus for the benefit of all who participle in the Lord's Supper. ${ }^{32}$

In Genesis chapter 2-3, the fruit of the Tree of Life has some implications for the Eucharist. R. Barron, asserts that from the freedom to eat of every tree in the Garden (Gen 2:15-17), God instructs Adam and Eve "to participate in his life through the joy of eating and drinking" ${ }^{33}$. At the Passover meal (Exodus 12) God hosted a banquet at which his human creatures share life with him and each other. The Passover meal was solemnized in memory of Yahweh, the Sovereign God who has manifested his power by delivering the Hebrew people from the yoke of slavery in Egypt. During the Passover meal of the New Covenant, Jesus pronounced the words of consecration, words which nobody before him had ever pronounced. "And he took bread, gave thanks and broke it, and gave it to them, saying "This is my body given for you; do this in remembrance of me. In the same way, after supper he took the cup, saying, this cup is the new covenant in my blood, which is poured out for you." 34

The Eucharist is indeed prefigured by prototypes in the Old covenant: the sacrifices of Abraham and Melchisedek; the manna in the desert; various sacrifices of the Old covenant especially that of the paschal lamb. Christians cannot forget the promise of 'wine and milk without money and without price' which was held out to everyone who thirsts and comes to the waters ${ }^{35}$ (Is 55:1-3). In the Wisdom literature, union with God is found in the figure of a table spread before him in the sight of His foes (Ps 23:5). The cumulative impact of these texts prepares one for the great eschatological supper of Christ. Jesus, therefore, places the Eucharist in the context of memorial feasts. It, according to His intention, involves a representation of His redemptive work. As a fulfillment of the Old Pasch, this Eucharist is the memorial par excellence of the new covenant. It is indelibly marked by the event of the Lord's passion and death of which, according to John Paul II, it is not only a reminder but the sacramental re-presentation..$^{36}$ The sacred Banquet is nothing other than the exchange of grace made possible by the nature of God. Like food and drink, Christ became accessible to human nature. Thus, he entered into the flesh of human beings so that humanity gets the divinized energy of God, the share of the Eternal God. He brings the mystery of God into history and is made accessible to human nature. That is why He insisted strongly: "unless you eat the flesh of the son of man and drink his blood you do not have life within you. Whoever eats my flesh and drinks my blood has eternal life, and I will raise him on the last day." ${ }^{37}$

Additionally, the Holy Eucharist makes present the sacramental offering of his unique sacrifice of the cross. When it is referred to as a memorial, it is not simply about a remembrance of the past events, but a proclamation of the mighty works wrought by God for Men/Women, whereby the past, present, future are made alive here and now. It is the sacrifice of the Lord's Pasch, which carries out redemption. Christ, by saying 'this is my body [...], this is my blood of the new and everlasting covenant; do this in memory of me. ${ }^{38}$ The blessed Lord manifested the Sacramental Character of the Eucharist. ${ }^{39}$ It is then that one realises that in the Eucharist, the sacrifice of the cross is re-present, and the very nature of the Eucharist brings forth the fruits of the Sacrifice of the cross.

Once again, Pope John Paul II teaches that the words of the institution are sacrificial in character because Christ spoke of a body that was broken and about the blood that was poured out for the forgiveness of sins. ${ }^{40}$ The reality of what he was to suffer on Calvary the following day was part of the meal he was celebrating with his apostles. It was a sacrificial meal. Jesus Christ gave the Eucharist to the pilgrim Church as a visible sacrifice by which the bloody sacrifice of the cross would be represented and remembered until the end of the world, and its salutary power

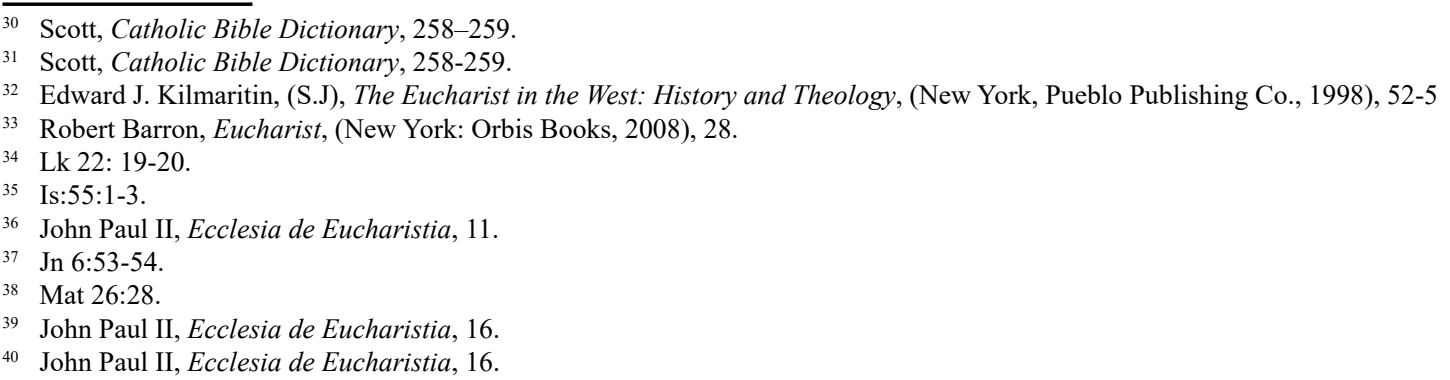


is applied to the forgiveness of the sins daily committed. ${ }^{41}$ Between the Eucharist and Calvary, there is one priest and one victim - Christ the Lord, but the manner of the offering differs because on the Cross it is a bloody sacrifice, but in the Eucharist it is unbloody. Verily, it is the same Christ who offered himself once in a bloody manner on the altar of the cross who is contained and is offered in an unbloody manner in the Eucharist. By receiving the Word of God, Bread and Wine as the body and blood of Christ, and Holy Spirit, believers are transformed into the Body of Christ. The Eucharist, therefore, makes present the Sacrifice of the Cross, it is not added to it, nor does it multiply it. What is repeated is the memorial celebration and demonstration of the Cross, whereby the unique and perpetually redemptive sacrifice of Christ shows itself as always efficacious in time..$^{42}$ It must be remembered that the Jewish tradition saw this communion sacrifice as the most complete sacrifice and by the time of Jesus saw the paschal meal as such a communion sacrifice. For J. Ratzinger, it was this meal that Jesus established as the memorial of his paschal sacrifice. It is a sacrifice in the sacramental sense where Christians are united to Christ by his action and transformed into his likeness. ${ }^{43}$ It is not a repetition of the historical moment of the cross. The actualization of Christ's sacrifice highlights the connection between God's redemptive operation and the Eucharist. The Eucharist embodies the entirety of redemption. Therefore, the Eucharist becomes integrated with the divine plan for salvation, fulfilled in the crucifixion at Calvary. Consequently, Barron $^{44}$ could rightly emphasize that sacrifice was the way to commune with the divine and with each other. In other words, a sacrifice is needed to reorder lives and restore communion with God. It is not something that God needs. It is a sign of thanksgiving, communion, and reparation where one seeks atonement. Christ's sacrifice is a life-giving activity of God out of love for his people who are created in the image of God. A new covenant was established with God with the body and blood of His only son.

During the last supper, Jesus Christ did not only transubstantiate bread and wine to be his Body and Blood but also that he offered to God the Father and instituted a true sacrifice of the 'New Covenant, which is the Eucharist. In both sacrifices (of the Cross and Eucharist) there is the same victim and priest, who is Christ the Lord. From the foregone, it can be firmly concluded that the Holy Communion as a foretaste of heavenly banquet is at the same time a memorial and sacrificial meal. Jesus affirms: "my flesh is food indeed and my blood is drink indeed."

\section{Eucharist, an Eschatological Meal}

For Pope John Paul II, the Holy Eucharist embodies a profound eschatological meaning. The actual presence of Christ and his sacrifice at the Last Supper are intertwined ${ }^{46}$ The reception of the Eucharist (Holy Communion) is a pledge of the ineffable communion with Christ in the life to come. In other words, although on earth and living in the present age, the communicant participates in the new life to come, the kingdom of God is His communion with humanity in the Holy Spirit, and already present in the Eucharist. The eschatological nature of the Eucharist affirmed in all patristic theology is of particular importance on the deification or divinization of man. The deification of man/woman is not simply a gift to be conferred in the future but a living reality in the present existence. ${ }^{47}$ Christ's uncreated and divinizing grace, which will make even the Human's body at one with the body of His glory, is already implanted in man/woman in this life and conduces to his deification. As an eschatological meal, the Eucharist has prime importance as the fount and apex of the Christian life. ${ }^{48}$

The early Christians, according to G.S. Sloyan, gathered two or three in the Lord's name. This is because "He [Christ] was believed to be in the midst of them (Matt 18:20) just as much as Yahweh was present to His people in that whole series of sacred meals, the Passover included, which were anticipatory of the messianic banquet of the end-time." ${ }^{49}$ The Church lives within the eschatological reality of an 'already' and 'not yet' achieved salvation. The Catholic believes that with the reception of the Holy Communion, he or she participates already in the Kingdom of God as he or she shares in the heavenly banquet. However, the definitive and fullness of the God's Kingdom and its heavenly banquet will be realized in eschaton or at the end of time. The Lord himself makes it clear to believers that "you may eat and drink at my table and in my kingdom" (Luke 22:30). The Eucharist is a "realized eschatology." It is a fulfillment of the shadows of the past and a foretaste of the Last Day, a present apprehension by the faith of the risen Lord whom believers shall possess at the Last Day. The Eucharist is preeminently the sacrament of Christian Hope and an anticipated eschatological banquet. In the Eucharist as a paschal banquet, the eschatological significance of the death, resurrection, and glorification of Christ is celebrated. For, Christ is reported to have said that "he who eats my

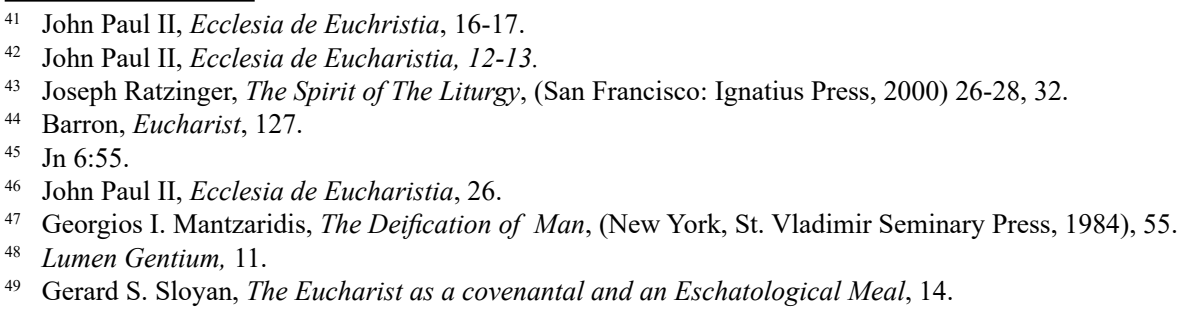


flesh and drinks my blood has eternal life and I will raise him on the last day." ${ }^{50}$ It can therefore be reiterated that what Pope Paul VI professes in mysterium fidei concludes this section:

At the Last Supper, on the night when He was betrayed, our Savior instituted the Eucharistic Sacrifice of His Body and Blood. He did this to perpetuate the Sacrifice of the Cross throughout the centuries until He should come again, and so to entrust to His beloved Spouse, the Church, a memorial of His Death and Resurrection: a sacrament of love, a sign of unity, a bond of charity, a paschal banquet in which Christ is eaten, the mind is filled with grace, and a pledge of future glory is given to us. ${ }^{51}$

\section{THE DOCTRINE OF TRANSUBSTANTIATION}

The doctrine of Transubstantiation had seen a long and incessant theological debate and misunderstanding among Christians since the institution of the sacrament of the Holy Communion by the Lord. One of the early Church fathers, Theodore of Mopsuestia (392-428 AD), a faithful witness to the faith of the Church and a Bishop was quoted by Pope Paul VI in his letter Mysterium Fidei, to have addressed the people in a very simple but incisive way on this issue. He inversely reminded the people: "The Lord did not say: This is the symbol of my body, and this is a symbol of my blood, but instead: This is my body and my blood. He teaches us not to look to the nature of what lies before us and is perceived by the senses because the giving of thanks and the words spoken over it, have changed it into flesh and blood." ${ }^{52}$ In the same perspective of the church's faith, the Council of Trent, without ambiguity, acknowledges that after the consecration of the bread and wine, Christ Jesus, both fully God and fully man, is really, truly and substantially contained in the Blessed Sacrament of the Holy Eucharist under the outward appearances of sensible things. ${ }^{53}$ Pope Paul VI could therefore affirm that in the Eucharist, Christ is present in "His humanity not only in His natural manner of existence at the right hand of the Father but also at the same time in the sacrament of the Eucharist in a manner of existing that one can hardly express in words but that human mind, illumined by faith, can come to see as possible to God and that Christians must most firmly believe." ${ }^{\prime 54}$ This is how the Catholic Church explains the doctrine of transubstantiation. One of the Catholic renowned transcendental theologians, Karl Rahner also added his voice to the debate explicating further that transubstantiation is simply a logical explanation of the Real Presence of Christ, a statement that in the Eucharist Christ is truly, really, and in his substance present. ${ }^{55}$ Rahner calls it a logical, ${ }^{56}$ not an ontic, ${ }^{57}$ explanation because the dogma of transubstantiation affirms neither more nor less than the word of Christ saying, 'This is my Body' ${ }^{58}$ Thus one can stipulate that all other supplementary explanations, and auxiliary theologizing fall within the 'ontic' sphere, and are not part of Catholic dogma.

\section{The Real Presence}

Catholic theology affirms strongly that in the sacrament of the Eucharist, the Body and Blood together with the soul and divinity, of Jesus the Christ is truly, really, and substantially contained. This presence is called 'real' and is not exclusive of other types of presence as if they could not be 'real', but it is present in the fullest sense: in other words, and according to Pope John Paul II, it is a substantial presence by which Christ, God, and man, makes himself wholly and entirely present. ${ }^{59}$ In explicating this theological issue of presence, Rahner had earlier on explained that something may, in a metaphorical or analogical sense, be said to be present in symbol or sign, or the memory or intention, or present in the hearts through love. In the case of the Eucharist, none of these meanings of 'presence' is what is meant by the statement "Real Presence of Christ in the Eucharist." 60

In other words, Christ is present in the Eucharist in His glorified being; matter and form; with His full underlying essence, wholly and entirely. The expression Real Presence implies also the substantial presence of Christ in the bread and wine. Substance refers to the being and the essence of an entity; in metaphysics, it is used to denote that which has to be in itself, and not just in another (accidents). ${ }^{61}$ It can be concluded from the above that Jesus is present in the most blessed Eucharist, in the fullness of His glory as He lives it now in heaven. It is not only that He "comes down" to

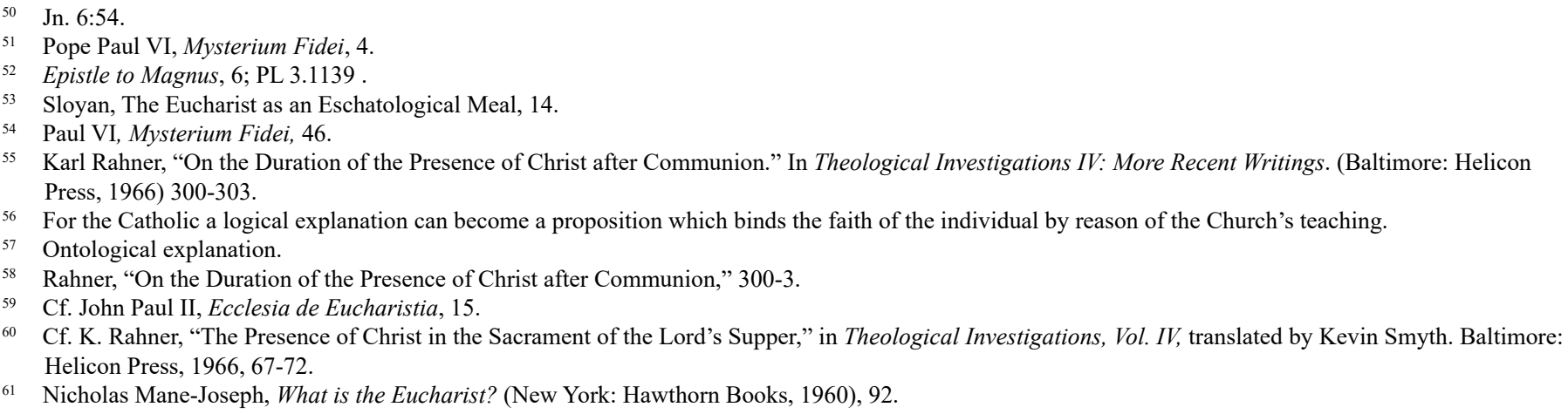


earth to be with humanity in the Eucharist, but also that the Eucharist brings humanity to Him as He is in heaven. It is in this perspective that made Thomas Aquinas stipulate that the Eucharist is the glorious and risen Lord Himself, as He lives and moves and acts now in His glorious body. ${ }^{62}$ The Council of Trent could not but affirmed that in the nourishing sacrament of the Holy Eucharist the Lord Jesus Christ, true God, and man, is truly, really, and substantially contained under the species of those sensible realities. ${ }^{63}$

It must be noted that the three adverbs, "truly, really, and substantially" are not intended as having different meanings. They are used simply to assert the reality of Christ's presence. Ratzinger stresses that the Lord is present in the believer's conscience, in his word, in his presence in the Eucharist. ${ }^{64} \mathrm{He}$ became flesh so that he might become bread. He gave himself to enter into the believer's hearts. In fact, Christ's presence in the Eucharist does not exist independently and in isolation, but forms part of his universal presence in the Church; it is an intensification of this universal presence, a sacramental manner of presence, which consequently symbolizes and affects another reality, his presence in the Church. Christ is integrally present, from the moment of the consecration; the true body of the Lord and his true blood is present in union with his soul and divinity.

The soul and divinity are present and inseparable from the Body and Blood ${ }^{65}$ This indivisible oneness of Christ means a permanent bond prevailing between the blood and body and the presence of Christ's soul under its indissoluble union with the body, oneness acquired at the moment of the Resurrection. ${ }^{66}$ It must consequently be recalled that the body given as Eucharistic food is the body in its glorious state, a state that is reunited with his body and soul at the moment of the resurrection and that makes any separation in the future impossible. The presence of Christ in the Eucharist is wholly and entirely in each of the species that has become Body and Blood by transubstantiation, wholly and entirely in each particle, meaning that the breaking of the bread does not divide Christ and that the Eucharistic presence of Christ endures as long as the Eucharistic species subsist. It can be concluded from the above that the Real presence is a theological term referring to the reality that occurs in the Mass.

\section{Transubstantiation and Eucharistic Conversion}

This section theologically elucidates further on how Christ is really, truly, and substantially present in the Holy Eucharist. In fact, the Church's argument is that this occurs through a unique and marvelous "conversion" of the substance of the bread and wine on the altar into the substance of the Body and Blood of Christ. It can therefore be implied that before the consecration of the bread and the wine, Christ's presence on the altar is diminished. However, upon the pronouncement of the words of consecration over the bread and wine from the priest, Christ becomes truly, really, and substantially present in the most Sacrament of the Holy Eucharist. ${ }^{67}$ St. Thomas Aquinas reiterates in clarifying that the only way this can come about is the conversion of the entire substance of the bread and substance of the wine into the entire substance of Christ. This conversion is appropriately called transubstantiation, for it is the instantaneous conversion of one entire substance into another. ${ }^{68}$

It must quickly be pointed out that there is no local motion in the Eucharist. Christ does not move to be present in the Eucharist. It is not as if Christ "moved" from heaven down to the altar. If that were true, He would cease to be present in heaven, which is false. Similarly, He would have to pass through all the intervening places to get there, which would take time.$^{69}$ And if He became present through local movement, He could only become present in one place at a time, and thus He could not be present simultaneously in all the consecrated hosts throughout the world. ${ }^{70}$ Therefore, by removing the possibility of local movement, it must be held instead that He becomes present through the other possibility, which is the conversion of the bread and wine into Him. ${ }^{71}$ Therefore in Catholic theology and understanding, this extraordinary conversion in the Eucharist is technically called "transubstantiation".

By transubstantiation, the Catholic Church refers to the direct conversion of the substance of bread and wine into the substance of Christ. Accordingly and without ambiguity or error, the Council of Trent teaches: "Because Christ our Redeemer said that it was truly his Body and blood that he was offering under the species of bread and wine, it has always been the conviction of the Church of God, that, by the consecration of the bread and wine, there takes place a change of the whole substance of bread into the substance of the Body of Christ our Lord and the whole substance of wine into the substance of his Blood. This change the holy Catholic Church has fittingly and properly

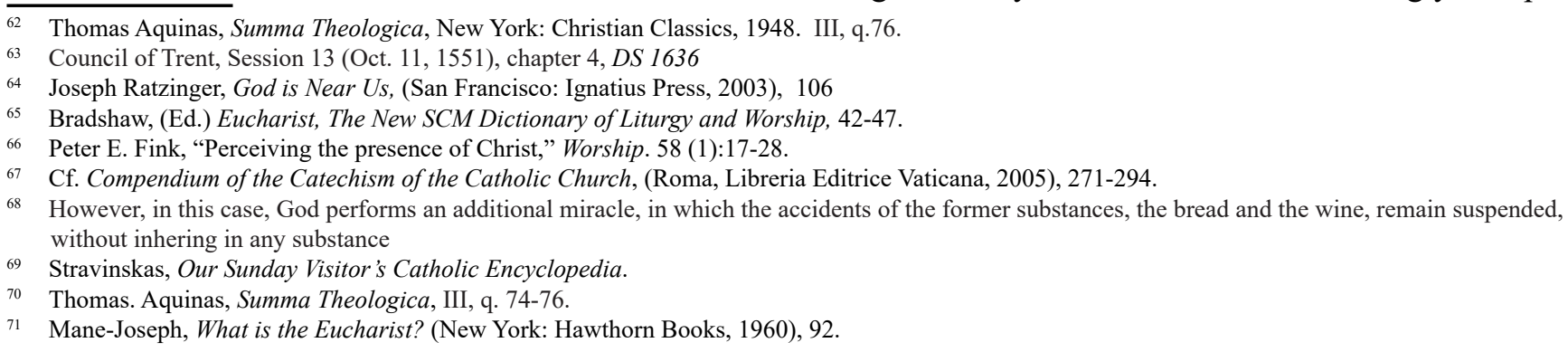


named transubstantiation." "72 Succinctly, one may conclude that the technical term "transubstantiation" shows us that this conversion of the bread and wine into Christ is not just an ordinary conversion. It is a unique conversion that has no direct parallel in the natural world. That in the Holy Eucharist, the whole substance of Christ is present "under" any part of the appearances of bread and wine.

For the Catholic Church and according to her magisterial teachings, Christ obtains no change by transubstantiation. ${ }^{73}$ Mysteriously transubstantiation does not involve any change in Christ; all the change is on the part of the substance of bread and wine, which are converted into Christ. In the Eucharist, Christ is not bilocated, nor moved, nor multiplied, nor divided. He is substantially present in the Eucharist not through a change in Him, but a conversion of the bread and wine into Him. Since this is a unique occurrence, one would look in vain for something similar in nature. An imperfect analogy can be made to the Incarnation. The Incarnation did not make any change in the divine nature of the Word, which is immutable. All the change was on the part of humanity which was assumed by the divine Person. ${ }^{74}$ Humanity thus gained an infinite dignity and a relation of union with the Person of the Word. Likewise, in the Eucharist, all the change is on the part of the substance of bread and wine which are converted into Christ. Christ Himself, present in the Eucharist, is neither changed by the action of transubstantiation, nor by anything that happens to the sacramental species, such as division or consumption. But under every part of the dimensions of the sacramental species, Christ is made present, whole, and unchanged. Therefore, one can affirm that the body and blood of Christ are each present in both the bread and wine in the Eucharist.

\section{CONCLUSION}

The study had emphasized the Holy Eucharist as the source and summit of the Christian life per Catholic theology. It is realized that God enters into covenant with his people and this is ratified with meal and blood foreshadowing the Eucharist as an eschatological banquet. Christ, who created and instituted the Eucharist continues, through the intervention of his Church to make an offering through the gift of his Body and Blood. The study also heightened the fact that the Eucharist is not like any natural change, but is entirely beyond the powers of nature and brought about purely by God's power (sola Dei virtute effecta). By divine power, the complete substance of the bread and wine are converted into the complete substance of Christ's Body and Blood. Hence this change is not formal, but a substantial one, therefore it can and indeed must - be called by a name proper to itself 'transubstantiation.' For, in the Holy Eucharist the Body and Blood, together with the soul and divinity, of the Lord Jesus Christ, that is the whole Christ is truly, really, and substantially contained.

\section{ABOUT AUTHOR}

Very Rev. Fr. Dr. Francis Appiah-Kubi is a Senior Lecturer at the Kwame Nkrumah University of Science and Technology, Kumasi, Ghana. He was the former Head of the Department of the Religious Studies Department at the Faculty of Social Science, KNUST. He is currently the Chairman of Tender Evaluation Panel (Goods and Services-Procurement), KNUST. He is a Ghanaian Theologian specialized in Ecclesiology and studies in African Traditional Religions.

\section{BIBLIOGRAPHY}

Aquinas T. Summa Theologica, New York: Christian Classics, 1948.

Barron R. Eucharist, (New York: Orbis Books, 2008).

Bradshaw, P.F. (Ed.), Eucharist, The New SCM Dictionary of Liturgy and Worship, (London: SCM Press, 2002).

Catechism of the Catholic Church, (CCC), 1337 \& 1341.

Compendium of the Catechism of the Catholic Church, (Roma, Libreria Editrice Vaticana, 2005), 271-294.

Congregation for the Doctrine of Faith, Some aspects of the church understood as communion, (Boston, Pauline Books and media), 1992.

Council of Trent, Session 13 (Oct. 11, 1551), chapter 4, DS 1636

Fink, P.E. "Perceiving the presence of Christ," Worship. 58 (1):17-28.

Garrigou-Lagrange R. "The Structure of Humani Generis", (La Sintesi tomistica), (Brescia, Queriniana, 1953).

Gratsch E. J. et al. (Eds.) Principles of Catholic Theology, (New York, Society of St. Paul, 1981).

John Paul II, Encyclical letter Ecclesia de Eucharistia, (Boston, Pauline Books and Media, 2003).

Kilmaritin, E.J. (S.J), The Eucharist in the West: History and Theology, (New York, Pueblo Publishing Co., 1998).

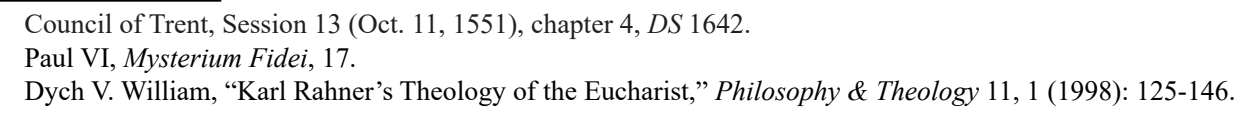


Ludwig O. Fundamental of Catholic Dogma, Illinois, (Tan Books and Publishers, (4 $4^{\text {th }}$ Edition), 1960).

Mantzaridis,G.I. The Deification of Man, (New York, St. Vladimir Seminary Press, 1984).

Mane-Joseph, N. What is the Eucharist? (New York: Hawthorn Books, 1960), 92.

Mathew,T. "Significance of Sacraments of Initiation," (PhD dissertation, Katholieke Universiteit Leuven, 2008).

McBrien R.P. Catholicism (San Francisco/New York, Harper/Collins Publishers, 1994).

Pius XII, Encyclical Letter Humani Generis, (Roma, Libreria Editrice vaticana, 1950).

Pope Paul VI. Encyclical letter on the Eucharist, Mysterium Fidei, (Rome, Libreria Editrice Vaticana, 1965).

Rahner, K. "On the Duration of the Presence of Christ after Communion." In Theological Investigations IV: More Recent Writings. (Baltimore: Helicon Press, 1966).

Ratzinger J. God is Near Us, (San Francisco: Ignatius Press, 2003).

Ratzinger J. The Spirit of The Liturgy, (San Francisco: Ignatius Press, 2000).

Roman Missal, Institutio Generalis.

Scott H. Catholic Bible Dictionary, (New York, Doubleday, 2009).

Second Vatican Council, Dogmatic Constitution on the Church, Lumen Gentium.

Second Vatican Council Constitution on Liturgy, Sacrosanctum Concilium.

Sloyan,G.S. The Eucharist as a covenantal and an Eschatological Meal, 14.

Stravinskas P.M. (Ed.), Our Sunday Visitor's Catholic Encyclopedia (Huntington: Our Sunday Visitor Inc., 1991).

William, D.V. "Karl Rahner's Theology of the Eucharist," Philosophy \& Theology 11, 1 (1998): 125-146. 